\title{
DIVERSITY OF SOIL MACRO FAUNA AND ITS ROLE ON SOIL FERTILITY IN MANGLID AGROFORESTRY
}

\author{
Aditya Hani* and Endah Suhaendah \\ Agroforestry Technology Research Institute \\ Jl. Raya Ciamis - Banjar Km. 4, Ciamis 46201, West Java, Indonesia \\ Received: 28 August 2018, Revised: 15 April 2019, Accepted: 30 April 2019
}

\begin{abstract}
DIVERSITY OF SOIL MACRO FAUNA AND ITS ROLE ON SOIL FERTILITY IN MANGLID AGROFORESTRY. Soil macro fauna is one of the bio indicators in determining the quality of the land. The total soil macro fauna is influenced by the climatice condition and land utilization pattern. Agroforestry is one of type land utilization that is expected to improve the soil fertility. Land utilization changing from monoculture into agroforestry is predicted to influence the soils macro fauna. This study is aims to find out the population of soil macro fauna before and after applying manglid agroforestry. The research was conducted in Cukangkawung, Tasikmalaya District, West Java Province. Sample of macro fauna was taken from non-productive land of tea plantations and one year after the land was planted by manglid + corn + peanut by using agroforestry. Samples were taken in Feb-March 2015 and once more in Feb-March 2016. The observation land area is 1 hectare that is divided into $1 \mathrm{mx} 1 \mathrm{~m}-16$ observation plots that was placed randomly. In each plot, a hole of $30 \mathrm{~cm}$ in depth was made and the dug out soil was placed on the plastic container. The collected macro fauna was counted and placed into a bottle that was filled with $70 \%$ alcohol. The macro fauna identification was conducted in LIPI zoology laboratory. The research shows that the diversity indexes for Shanon and Margalef on manglid agroforestry are higher than on the ex tea land. Factors that influence the soil macro fauna diversity improvement is $\mathrm{pH}$, low temperature of soil and high soil moisture. Soil macro fauna becomes organic decomposer in agroforestry for about $56,25 \%$ and $20 \%$ in non-productive land of tea plants.
\end{abstract}

Keywords: Agroforestry, bio indicator, macro fauna, land of tea plants, decomposer

KERAGAMAN MAKROFAUNA TANAH DAN PERANNYA TERHADAP KESUBURAN TANAH PADA AGROFORESTRY MANGLID. Makrofauna tanah merupakan salah satu bioindikator yang menunjukan kualitas suatu lahan. Kelimpaban makrofauan tanah dipengarubi oleb kondisi iklim dan polapenggunaan lahan. Agroforestri merupakan salah satu bentuk. sistem pemanfaatan laban yang diharapkan dapat meningkatkan kesuburan tanah. Perubahan pola penggunaan lahan dari monokultur menjadi agroforestri diduga memberi pengarub terbadap kelimpahan makrofauna tanah. Penelitian ini bertujuan untuk mengetahui populasi makrofauna tanah sebelum dan setelah penerapan pola agroforestri manglid. Penelitian dilaksanakan di Desa Cukangkawnng, Kecamatan Sodongbilir, Kabupaten Tasikmalaya. Pengambilan sampel makrofauna dilakukan pada lahan teb tidak produktif, setabun setelah lahan tersebut ditanami dengan pola agroforestri yaitu manglid+jagung+kacang. Luas lahan pengamatan 1 ha yang dibagi menjadi 16 plot pengamatan yang berukuran 1 $m \times 1 \mathrm{~m}$ dan diletakkan secara acak. Pada setiap plot pengamatan dikeruk tanah sedalam $30 \mathrm{~cm}$ dan ditempatkan pada bak plastik. Makrofauna yang tertangkap dihitung jumlabnya dan dimasukkan ke dalam botol yang telab berisi alkohol 70\%. Identifikasi makrofauna tanah dilakukan di Laboratorium Zoologi LIPI, Cibinong. Hasil penelitian menunjukan babwa indeks keanekaragaman jenis Shannon dan indeks kekayaan jenis Margalef pada agroforestri manglid nilainya lebih tinggi dibandingkan laban bekas teh. Faktor yang mempengarubi peningkatan keanekaragaman makrofauna tanah adalah peningkatan $\mathrm{pH}$, subu tanah lebih rendah dan kelembapan tanah yang lebih tinggi. Makrofauna tanah yang berperan sebagai pengurai bahan organik di lahan agroforestri sebesar 56,25\% sedangkan di laban teh tidak produktif $20 \%$.

Kata kunci: Agroforestri, bioindikator, makrofauna, perkebunan teh, pengurai

*Corresponding author: adityahani@gmail.com 


\section{INTRODUCTION}

Soil organism has an important role as chemical and ecosystem engineer, and biological regulator (Widyati, 2013). Soil macro fauna is one of soil organisms that have many types and advantages. Its existence is influenced by biotic and abiotic factors inside the soil (Dwiastuti, 2016). The biotic factors are micro flora and plant species, while the abiotic factors are physical and chemical characteristic of soil. The physical characteristic consists of soil structure and texture, while the soil chemical characteristic consists of $\mathrm{pH}$, salinity, soil organic materials and minerals (Nurrohman, Abdulkadir, \& Sri, 2015). Water inside the soil influences the number of nematodes. However, the antagonist biotas are able to breed inside less water - soil (Swibama, Putra, Susilo, Hairiah, \& Suprayogo, 2010). Dewi, Handayani, and Sumani (2008) wrote that land management can increase or decrease the soil macro fauna population.

Agroforestry as land utilization pattern is applied by many farmers. They expect gaining more income and harvesting products continuously by applying the agroforestry technique. Farmers can choose it because it can guarantee and improve the food needs, quality of nutrition, and because of culturate factor (Tjatjo, Basir, \& Umar, 2015). Tree in agroforestry system will produce a better environment. Suryani and Dariah (2012) wrote that tree has canopy to protect soil from erosion, while root of tree will prevent the leaching the soil nutrients. This can maintain the soil organic material, land fertility, and the numbers of soil organisms.

Nowadays, there is a lot of tea garden with low productivity. One of the causes is low soil fertility. It is because the biomass of tea leafs is imbalanced with the fertilizing activity. The input of organic material into the land is less because of less litter produced by tea leafs. Some farmers in Tasikmalaya change tea plants into seasonal plants or woods or agroforestry. Manglid is one of the developed tree species in Tasikmalaya because manglid is suitable to the land condition (mountain/plateau). Land utilization that is changed from tea garden monoculture into manglid agroforestry with seasonal plants gives effect on the number of population of soil macro fauna. Agroforestry causes land utilization, organic and non-organic fertilization, and litter of main plant and harvesting product of seasonal plants. Soil fauna is used as soil bio-indicator because it has a high respond to soil utilization, soil characteristic and climate (Swibama et al., 2010). CastroHuerta, Falco, Sandler and Coviella (2015) wrote that macro fauna activity is influenced by climate, soil characteristic, and organic residue. Macro fauna has a role in decomposing organic material where the residue is mineralized by the bacteria (Hilwan \& Handayani, 2013). The research is aimed to compare the number of population of soil macro fauna before and after manglid agroforestry. The comparison is aiming to determine the effect of agroforestry on soil biological fertility.

\section{MATERIAL AND METHOD}

\section{A. Research Site}

The research was conducted in Cukangkawung, Sodonghilir Sub-District of Tasikmalaya, West Java Province from February until March 2015 and February until March 2016. Cukangkawung's position is $107^{\circ} 18^{\prime} 30^{\prime \prime}$ $108^{\circ} 25^{\prime} 00^{\prime \prime}$ of East longitude and $07^{\circ} 04^{\prime} 30^{\prime \prime}$ $07^{\circ} 11^{\prime} 00^{\prime \prime}$ of South latitude, and $850 \mathrm{~m}$ above sea level (masl). The required tools were hoe, plastic container, bottle, roll meter, label, tweezers, GPS, soil tester, and stationary. The required material was alcohol $(70 \%)$.

\section{B. Method}

Sample of macro fauna was taken from non-productive land of tea plants and one year after the land was planted by manglid + corn + peanut by using agroforestry, the measurements were repeated. The observed land area was 1 hectare that was divided into ramdomly placed $1 \mathrm{~m} \times 1 \mathrm{~m}$ - i.e. 16 observation plots which were repeated three times so that the total number of observation plots was 48 plots.. In each plot, a hole with $30 \mathrm{~cm}$ depth was made 
and the dug outsoil was placed into the plastic container. The macro fauna was counted and placed into the bottle that was filled with $70 \%$ alcohol. The macro fauna identification was conducted in LIPI (Indonesian Institute of Sciences) zoology laboratory.

\section{Analysis}

The obtained data and information of macro fauna was analyzed by using the Shannon Wienner diversity index and Margalef species wealth index by using the formulation as follow: Remark:

$H^{\prime}=-\sum_{i=1}^{n}\left(\frac{n i}{N}\right) \operatorname{Ln}\left(\frac{n i}{N}\right)$

$R^{\prime}=\sum \frac{s-1}{\operatorname{Ln} N}$

$H^{\prime}=$ Shannon - Wienner diversity index

$R^{\prime}=$ Margalef species wealth index

$n i=$ number of population of each species

$N=$ total number of all population $s=$ number of species

To find out the relationship among the abiotic variables (soil $\mathrm{pH}$, temperature, and moisture), Shannon - Wienner diversity index, and Margalef species wealth index, Pearson correlation test by using SPSS is applied.

\section{RESULTS AND DISCUSSION}

\section{A. Macro Fauna Species Diversity}

Based on the observation there are 5 species of macro fauna at non-productive tea garden that are classified into ordo of Ophistopora, Coleoptera, Scolopendromorpha and Himenoptera. On manglid agroforestry land, those species increase up to 16 species from various ordo, i.e. Ophistopora, Haplotaxida, Tricladida, Isoptera, Coleoptera, Scolopendromorpha, Araneae, Orthoptera, Himenoptera, Diplura, Blattodea, and Isopoda. Those macro fauna functions are detritivore herbivore, and predator (Table 1). Formicidae

Table 1. Macro fauna species on ex tea garden area and manglid agroforestry

\begin{tabular}{|c|c|c|c|c|c|c|}
\hline \multirow[b]{2}{*}{ No } & \multirow{2}{*}{$\begin{array}{l}\text { Macro Fauna } \\
\text { Species }\end{array}$} & \multirow[b]{2}{*}{ Ordo } & \multirow[b]{2}{*}{ Family } & \multicolumn{2}{|c|}{ Number of Macro Fauna } & \multirow{2}{*}{$\begin{array}{c}\text { Role/ } \\
\text { Function }\end{array}$} \\
\hline & & & & $\begin{array}{c}\text { Ex-garden } \\
\text { tea area } \\
\end{array}$ & Manglid af & \\
\hline 1 & Pheretima spp. & Ophistopora & Megascolecidae & 28 & 142 & Detritivor \\
\hline 2 & Eisenia sp. & Haplotaxida & Lumbricidae & - & 7 & Detritivor \\
\hline 3 & Caenoplana sp. & Tricladida & Geoplanidae & - & 1 & Detritivor \\
\hline 4 & Macrotermes sp. & Isoptera & termitidae & - & 1 & Herbivore \\
\hline 5 & Oryctes sp. & Coleoptera & Scarabaeidae & 1 & 1 & Herbivore \\
\hline 6 & Scolopendra sp. & Scolopendromorpha & Scolopendridae & 1 & 12 & Predator \\
\hline 7 & Spider & Araneae & - & - & 3 & Predator \\
\hline 8 & Gryllus sp. & Orthoptera & Gryllidae & - & 6 & Herbivore \\
\hline 9 & Phyllophaga sp. & Coleoptera & Scarabaeidae & - & 61 & Herbivore \\
\hline 10 & Solenopsis sp. & Himenoptera & Formicidae & 39 & 9 & Predator \\
\hline 11 & Tenebrio sp. & Coleoptera & Tenebrionidae & 7 & - & Herbivore \\
\hline 12 & $\begin{array}{l}\text { Gnathaphanus } \\
\text { subolivaceus }\end{array}$ & Coleoptera & Carabidae & - & 10 & Detritivor \\
\hline 13 & Agoponia sp. & Coleoptera & Scarabaeidae & - & 4 & Detritivor \\
\hline 14 & Campodea sp. & Diplura & Campdeidae & - & 3 & Detritivor \\
\hline 15 & Odontoponera sp. & Himenoptera & Formicidae & - & 2 & Detritivor \\
\hline 16 & Blatta sp. & Blattodea & Blattidae & - & 1 & Detritivor \\
\hline \multirow[t]{2}{*}{17} & Altriniscus sp. & Isopoda & - & - & 4 & Detritivor \\
\hline & & & Total & 76 & 267 & \\
\hline
\end{tabular}

Remark: af = agroforestry 
Tabel 2. Diversity index number of macro fauna species in ex - tea garden and manglid agroforestry

\begin{tabular}{cccccc}
\hline Land & Family & Species & Population & H' & R' $^{\prime}$ \\
\hline Ex - tea garden & 5 & 5 & 76 & 0.33 & 0.98 \\
Manglid af & 14 & 16 & 267 & 0.63 & 1.92 \\
\hline
\end{tabular}

Remark: af = agroforestry

Table 3. Measurement on $\mathrm{pH}$, temperature, and soil moisture in research site

\begin{tabular}{lcc}
\hline \multicolumn{1}{c}{ Parameter } & Ex -tea Garden & Agroforestry of manglid \\
\hline $\mathrm{pH}$ & 4.9 & 6.6 \\
Soil Temperature & $29.5^{\circ} \mathrm{C}$ & $26.2{ }^{\circ} \mathrm{C}$ \\
Soil Moisture & $0.5 \%$ & $3.8 \%$ \\
\hline
\end{tabular}

Table 4. Result of test of correlation among ph, temperature, and soil moisture on shannon diversity index and margalef wealth index for macro fauna species

\begin{tabular}{rlcc}
\hline \multirow{2}{*}{ No } & \multirow{2}{*}{ Environment Variables } & \multicolumn{2}{c}{ Pearson Correlation Value } \\
\cline { 3 - 4 } & & Shannon Index & Margalef Index \\
\hline 1 & $\mathrm{pH}$ & $1^{*}$ & $1^{*}$ \\
2 & Soil Temperature & $-1^{*}$ & $-1^{*}$ \\
3 & Soil Moisture & $1^{*}$ & $1^{*}$ \\
\hline
\end{tabular}

$\operatorname{Remark}^{*}=$ Very High Correlation

family (insect class) is a family with the highest number of species on ex-tea garden land. The research is matching to the research of (Ernawati, 2008). She wrote that formicide family is the dominant family of the macro fauna that was found in ex gold mining area in Jampang, South Sukabumi. In manglid agroforestry, family with the highest number of species is from Megscolecidae family (Oligochaeta class). Based on Table 1, Pheretima sp. is the most abundant number of soil macrofauna species. This is because Pheretima sp. is able to adapt to low soil $\mathrm{pH}$ and low organic matter. Therefore, Pheretima sp. can be found in post coal mining field in East Kalimantan (Nugroho, Widuri, \& Sayektiningsih, 2018).

Species diversity index number and Margalef Wealth Index on ex - tea garden is lower $(0.33$ and 0.98 ) than diversity index after transforming into manglid agroforestry (0.63 and 1.92). However, its index is lower than agroforestry of sengon and pineapple (1.1) (Wulandari, Sugiyanto, \& Wiryanto, 2007). It is because agroforestry of manglid and seasonal plants is young, still one year since it was planted. That makes the size of manglid tree is still small and land is covered by dominant seasonal plants. Meanwhile the agroforestry between sengon and pineapple has been applied longer than on the manglid. Diversity index of homogeneus tropical forest showed that wealth index of soil fauna is in the middle level (1.174 and 1.153) (Sari, 2014). Hilwan and Handayani (2013) said that land covering activity was correlated to time period. Therefore in the beginning of planting activity, generally, the diversity of macro fauna is low. It is similar to the ex-area that is beeing reclaimed, where the diversity index is low as well (1.15).

\section{B. The influence of $\mathrm{pH}$, Temperature, and Soil Moisture on Macro Fauna Diversity}

Environment abiotic factor highly determines the structure of soil fauna community(Peritika, 2010a). pH, temperature, and soil moisture influence the diversity of 
soil fauna function (Bio Intelligence Service (BIS), 2010). Measurement results of $\mathrm{pH}$, temperature, and soil moisture in the research site is shown in Table 3. Result of Pearson Test on correlation among $\mathrm{pH}$, temperature, soil moisture on Shannon diversity index and Margalef Wealth diversity is shown in Table 4.

Table 4 shows a very high correlation (1 or -1) among $\mathrm{pH}$, temperature, and soil moisture on diversity index and wealth index of macro fauna. The positive correlation shows that the increase and decrease of a variable will be followed by the increase or decrease of an other independent variables. On the contrary, the negative correlation shows that the increase of a variable will be followed by the decrease of the other variables (Peritika, 2010b).

The increased soil $\mathrm{pH}$ of the transformed land from ex - tea garden to manglid agroforestry causes the diversity and wealth of macro fauna species. Increase in soil $\mathrm{pH}$ due to fertilization in manglid agroforestry. Farmer added manure every planting crops. Worm likes to live inside neutral - basic soil ( $\mathrm{pH} 6-7.2$ ) because the soil nutrition is abudanly available in this soil (Maftu'ah \& Susanti, 2009). Suheriyanto (2013) wrote that diversity index of fauna species in Bromo is the lowest. It is probably caused by the low soil $\mathrm{pH}$. Meanwhile in the Pananjakan area the $\mathrm{pH}$ is higher, it has higher diversity of soil macro fauna than Bromo.

Soil temperature is one of the abiotic factors that influence the availability of soil fauna species. The increasing of soil temperature decreases the diversity and wealth of soil macro fauna species. Land with good vegetation canopy has low soil temperature and high soil moisture that has higher composition of soil macro fauna than the open space area (farm land area) (Qudratullah, Setyawati, \& Yanti, 2013).

Correlation value of soil moisture between the diversity and wealth index of macro fauna species is positive. Higher moisture of soil will make higher index of diversity and wealth of macro fauna species. This is caused by the improvement of soil macro fauna activities that is caused by the soil moisture (Bio Intelligence Service (BIS), 2010). The organic fertilization and the litter of seasonal plants in manglid agroforestry increases the soil moisture. Lalthanzara (2011) wrote that soil moisture is a factor that give the highest influence for the improvement of worm population. Therefore, more land canopy will increase macro fauna population.

\section{Macro Fauna as Detritivore on Soil Fertility}

Soil macro fauna is consisted of a huge number of different organisms that live on, in, and inside pores of soil surface. Macro fauna is found within $60-80 \mathrm{~cm}$ depth of soil. However most zoo mass is in the $0-30 \mathrm{~cm}$ of depth of humus (Bragina, 2016).

Macro fauna from Oligochaeta, i.e. Pheretima sp., Eisenia sp and Caenoplana sp. classes, and six species from Gnathapanus subolivaceus, Agoponia sp., Campodea sp., Odontoponera sp., Blatta sp. and Altriniscus sp. classes functioned as detritivore. Proportion from various tropical soil macro fauna is shown in Figure 1. On ex - tea garden, there are $20 \%$ macro fauna as detritivore, meanwhile on manglid agroforestry, macro fauna as detritivore is dominant $(56.25 \%)$ than the others.

Worm is the main component of soil macro fauna community in most ecosystems and most macro fauna biomass. Worm has important function in organic material decomposition. Worm eats and destroys litter and other parts of dead plants. It improves soil nutritious cycle through a fast joining process from soil detrition into mineral soil. Beside, its mucus can improve the activity of other beneficial soil microorganisms. Then, organic production becomes a succeeded process. Therefore, in short term period, the significant effect is a huge concentration of soil nutrition $(\mathrm{N}, \mathrm{P}, \mathrm{K}$, and $\mathrm{Ca}$ ) that is easy to be assimilated by the plants. Worm is also known as an organism that can improved nitrogen mineralization through direct and indirect effect on microorganisms. The improve of organic $\mathrm{C}$ and $\mathrm{N}$ transfer 

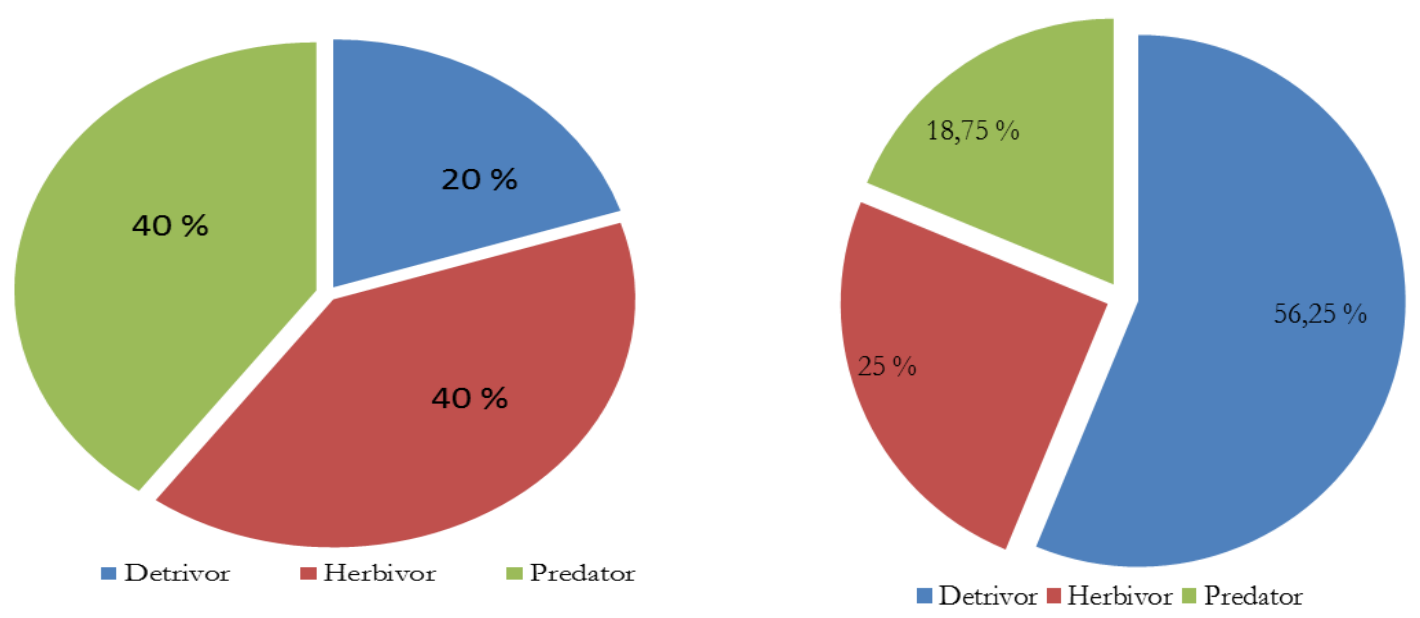

Figure 1. Structure of macro fauna on (a) Ex-tea garden and (b) Manglid agroforestry

becoming soil aggregate shows that worm potentially is able to facilitate soil organic material stabilization and its accumulation in farming system (Anwar, 2009; Bhadauria \& Saxena, 2010). Worm is also effective in keeping the bio-geo-chemical process inside the soil and reducing bad nutrition (when it is in over dose), such as $\mathrm{Fe}, \mathrm{Al}, \mathrm{Ms}, \mathrm{Cu}$, and $\mathrm{Zn}$ (Anwar, 2009). Worm can improve plant's growth through mineralization improvement. There are various effects of worm in this plant's growth. It is depending on the soil characteristic, such as availability of nutrition, mineral, organic materials, and texture (Laossi et al., 2010).

Based on Table 1, worm population on manglid agroforestry is higher than in extea garden, as written by Bhadauria \& Saxena (2010) where the different land utilization can affect population and diversity of earthworm. The most ideal worm breeding process is on $\mathrm{pH}$ is $6-7.2$ (Maftu'ah \& Susanti, 2009). The $\mathrm{pH} 6.6$ on manglid agroforestry land. It is an ideal condition for worm to breed. Considering the important role of worm as detritivore, then land utilization strategy has to promote the beneficial soil organisms, such as worm through the appropriate vegetation management to maximize its benefit for the whole agroecosystem (J, D, Quintero, Velásquez, \& Lavelle, 2012).
Soil insect is insect that temporary or permanently live inside the soil. Insect has a function as a detritivore or an organism that can reorganize the available organic material for green plants, so it can return the soil fertility (Sari, 2015). Soil insect eats live or dead plant. Insect can accelerate the decomposition of organic material. Soil insect is highly dependent on availability of energy and source of food, such as organic materials and live biomass and all of them are related to carbon cycle inside the soil. The availability of energy and soil nutrition can keep the existence of soil insect, and it will make the activity of soil insect in sustainable (Ruslan, 2009).

Based on Table 1, detritivore insect on manglid agroforestry has more number than on ex-tea garden area. On manglid agroforestry land, number of vegetation and litter is also greater than on ex-tea garden. Therefore, there is more food for soil insects. The availability of fauna can be a parameter of soil quality. The soil fauna as bio-indicator of soil fertility must be in relatively abundant number (Ibrahim, 2014). In this research, number of macro fauna on manglid agroforestry is more than on ex-tea garden (276 species and 76 species).This shows that soil fertility on manglid agroforestry is better than on the ex-tea garden. 


\section{CONCLUSION}

Transformation of land utilization from tea monoculture to manglid agroforestry and seasonal plants causes change in the population of soil macro fauna. Manglid agroforestry pattern has higher value in Shannon Diversity Index and Margalef Wealth Index than the ex-tea garden. The influencing factors of the variety improvement of soil macro fauna is $\mathrm{pH}$ improvement, lower soil temperature, and higher soil moisture. Macro fauna as organic decomposer on agroforestry land is higher $(56,25 \%)$ than on ex-tea garden $(20 \%)$. This condition is expected to improve the soil fertility, in line with the improvement of soil macro fauna population.

\section{ACKNOWLEDGEMENT}

The authors want to say thank to the Agroforestry Research and Development Institute for giving us trust in doing this research that was also supported by the available facilities and fund. We also want to say thank to our technicians for helping us in collecting data and information and in managing research fund.

\section{REFERENCES}

Anwar, E. K. (2009). Effectiveness of Anwar, E. K. (2009). Efektivitas Cacing Tanah Pheretima bupiensis, Edrellus sp. dan Lumbricus sp. dalam proses dekomposisi bahan organik. Jurnal Tanah Tropika, 14(2), 149-158.

Bhadauria, T., \& Saxena, K. G. (2010). Role of Earthworms in Soil Fertility Maintenance through the Production of Biogenic Structures. Applied and Environmental Soil Science, 816073, 1-7.

Bio Intelligence Service (BIS), E. C. (2010). Soil biodiversity: Functions, threats and tools for policy makers. Technical Reports 2010. Paris, france. doi://10.2779/14571.

Bragina, T.M. (2016). Soilmacrofauna (invertebrates) of Kazakhstanian Stipa lessingiana dry steppe. Hacquetia, 15(2), 105-112.

Castro-Huerta, R. A., Falco, L. B., Sandler, R. V., \& Coviella, C. E. (2015). Differential contribution of soil biota groups to plant litter decomposition as mediated by soil use. PeerJ, 1-14.

Dewi, W. S., Handayani, P., \& Sumani. (2008). Keragaman dan layanan ekologi makrofauna epigeik pada pertanaman wortel.Sains Tanah, 5(II), 113-120.

Dwiastuti, S. (2016). Kajian tentang kontribusi cacing tanah dan perannya terhadap lingkungan kaitannya dengan kualitas tanah. Prosiding Seminar Nasional IX Pendidikan Biologi FKIP UNS, 9(1), 448-451.

Ernawati. (2008). Soil fauna in the stratification of second-hand soil mining in Jampang, South Sukabumi. Zoo Indonesia, 17(2), 83-91.

Hilwan, I., \& Handayani, E. P. (2013). Keanekaragaman Mesofauna dan Makrofauna Tanah pada Areal Bekas Tambang Timah di Kabupaten Belitung, Provinsi Kepulauan Bangka-Belitung. Jurnal Silvikultur Tropika, 4 (1)(April), 35-41.

Ibrahim, H. (2014). Keanekaragaman mesofanana tanah daerah pertanian apel Desa Tulungrejo Kecamatan Bumiaji Kota Batu sebagai bioindikator kesuburan tanah dan bahan ajar cetak biologi SMA. UMM Malang.

J, S., D, F. \&, Quintero, C., Velásquez, E., \& Lavelle, P. (2012). Interactive effects of plants and earthworms on the physical stabilization of soil organic matter in aggregates. Plant Soil, 359, 205-214.

Lalthanzara, H. (2011). Population dynamics of earthworms in relation to soil physicochemical parameters in agroforestry systems of Mizoram, India, (May 2014).

Laossi, K.-R., Ginot, A., \& K.-R. L. \& A. G., Noguera, D. C., Blouin, M., \& Barot, S. (2010). Earthworm effects on plant growth do not necessarily decrease with soil fertility. Plant Soil, 328, 109-118.

Maftu'ah, E., \& Susanti, M. A. (2009). Komunitas cacing tanah pada beberapa penggunaan lahan gambut di Kalimantan Tengah. Berita Biologi, 9(4), 371-378.

Nugroho, A. W., Widuri, S. A., \& Sayektiningsih, T. (2018). Earthworm population at the post coal mining field in East Kalimantan. Indonesian Journal of Forestry Research, 5(2), 81-93.

Nurrohman, E., Abdulkadir, R., \& Sri, W. (2015). Keanekaragaman makrofauna tanah di kawasan perkebunan coklat (Theobroma cacao 
1. ) sebagai bioindikator kesuburan tanah dan sumber belajar biologi. Jurnal Pendidikan Biologi Indonesia, 1(2), 197-208. doi://10.22219/jpbi. v1i2.3331.

Peritika, M. Z. (2010b). Keanekaragaman makrofauna tanah pada berbagai pola agroforestri laban miring di Kabupaten Wonogiri, Jawa Tengah. Fakultas Matematika dan Ilmu Pengetahuan Alam Universitas Sebelas Maret, Surakarta.

Qudratullah, H., Setyawati, T. R., \& Yanti, A. H. (2013). Keanekaragaman cacing tanah (Oligochaeta) pada tiga tipe habitat di Kecamatan Pontianak Kota. Protobiont, 2(2), 56-62.

Ruslan, H. (2009). Komposisi dan keanekaragaman serangga permukaan tanah pada habitat hutan homogen dan heterogen di Pusat Pendidikan Konservasi Alam (PPKA) Bodogol, Sukabumi, Jawa Barat. VIS VITALIS, 2(1), 43-53.

Sari, M. (2014). Identification of Decomposer Insects in Lowland Tropical Forest Land Surface (Case Study at UNILAK Arboretum and Campus Complex with Area of $9.2 \mathrm{Ha}$ ). Bio Lectura, 2(1), 63-72.
Suheriyanto, D. (2013). Diversity of soil fauna in Bromo Tengger Semeru National Park as a bioindicator of high sulfur soil. Saintis, 1(2), 29-38.

Suryani, E., \& Dariah, A. (2012). Peningkatan produktivitas tanah melalui sistem agroforestri. Jurnal Sumberdaya Lahan, 6(2), 101-109.

Swibama, I. G., Putra, D., Susilo, F. X., Hairiah, K., \& Suprayogo, D. (2010). No Title. J. HPT Tropika, 10(1), 20-28.

Tjatjo, N. T., Basir, M., \& Umar, H. (2015). Hutan Desa Namo Kecamatan Kulawi Kabupaten Sigi. Jurnal Sains dan Teknologi Tadulako, 4(3), 55-64.

Widyati, E. (2013). The Importance of Functional Diversity of Soil Organisms to Land Productivity. Tekno Hutan Tanaman, 6(1), 2937.

Wulandari, Sugiyanto, \& Wiryanto. (2007). Decomposition of crop organic matters and their influence to diversity of soil mesofauna and macrofauna under Paraserianthes'stand (Paraserianthes falcataria). Bioteknologi, 4(1), 20 27. 